\title{
A Comparison of the Human Buccal Cell Assay and the Pollen Abortion Assay in Assessing Genotoxicity in an Urban-Rural Gradient
}

\author{
Alan da Silveira Fleck, Mariana Vieira, Sergio Luís Amantéa and Claudia Ramos Rhoden* \\ Oxidative Stress and Air Pollution Laboratory, Universidade Federal de Ciências da Saúde de Porto Alegre \\ (UFCSPA), Sarmento Leite Street, 245, Room 9. Porto Alegre 90050-170, Rio Grande do Sul, Brazil; \\ E-Mails: alansfleck@hotmail.com (A.S.F.); mariana_v007@hotmail.com (M.V.); \\ samantea@terra.com.br (S.L.A.) \\ * Author to whom correspondence should be addressed; E-Mail: crhoden@ufcspa.edu.br; \\ Tel.: +55-51-3303-8800; Fax: +55-51-3303-8794.
}

Received: 18 July 2014; in revised form: 18 August 2014 / Accepted: 21 August 2014 /

Published: 27 August 2014

\begin{abstract}
Air pollution is exacerbated near heavy traffic roads in cities. Air pollution concentration and composition vary by region and depend on urban-rural gradients. The aim of this study was to evaluate the distribution of air pollution in areas of varying population densities and to compare plant biomonitoring with an established biomarker of human exposure to traffic-related air pollution in children. The areas of study were selected near a major street in 3 different regions. Areas A, B and C represent high, intermediate and low population densities, respectively. Micronucleus assay, an established biomarker of human exposure, was performed in children from these areas. For a plant biomonitoring assay, the pollen abortion assay was performed on Bauhinia variegata in these areas. $\mathrm{NO}_{2}$ and $\mathrm{O}_{3}$ concentrations were determined by passive sampling. We report here that the pollen abortion frequency in Bauhinia variegata is correlated with $\mathrm{NO}_{2}$ concentration $(P=0.004)$ and is strongly associated with vehicular flow and population density in the studied areas. Micronuclei frequency in buccal cells of children was higher in the regions with more degree of urbanization $(P<0.001)$ following the same pattern of $\mathrm{O}_{3}$ concentrations $(P=0.030)$. In conclusion, our results demonstrate that high concentrations of air pollutants in Porto Alegre are related to both human and plant genotoxicity. Areas with different concentration of pollutants demonstrated to have an urbanization gradient dependent pattern which also reflected on genotoxic damage among these areas.
\end{abstract}


Keywords: micronucleus; air pollution; biomonitoring; bioindicator; passive sampling; genotoxicity; ozone; nitrogen dioxide

\section{Introduction}

Air pollution is a mixture of gaseous and particulate pollutants at disproportionate concentrations and is constantly modified by sunlight and temperature. Traffic-related pollution consists of multiple toxic moieties, including particulate matter $(\mathrm{PM})$, nitrogen dioxide $\left(\mathrm{NO}_{2}\right)$, ozone $\left(\mathrm{O}_{3}\right)$, polycyclic aromatic hydrocarbons (PAHs), metals and volatile organic compounds (VOCs) [1]. Air pollution is exacerbated near heavily trafficked roads in large cities. However, the concentration and composition of the pollutants has high variability in different regions, and it is dependent on the urban-rural gradient [2]. The variability in air pollution patterns throughout urban areas is strongly associated with traffic emissions and has a direct effect on the health of those who live near heavily trafficked routes. Thus, the density of neighborhood traffic is associated with exposure to higher doses of pollutants and leads to adverse health impacts such as respiratory disease, cardiovascular disease and lung cancer [3-7].

Because one of the main outcomes of air pollution exposure is cancer, evaluating the genotoxic effects of air pollution in an exposure population is critical. Multiple studies have utilized the micronucleus assay to demonstrate a relationship between air pollution and genotoxic effects [8-10]. In addition, research has shown increased micronuclei frequency in workers who are chronically exposed to traffic-related pollution in an urban environment [11], including gas station attendants [10], traffic police [12] and tunnel workers [13]. Compared to other biomarkers of genotoxicity, the micronucleus assay in buccal cells is a useful, noninvasive and simple method for monitoring genetic damage in humans since oral epithelial cells represent a preferred target population for early genotoxic events induced by carcinogenic agents introduced via inhalation [14].

A reliable alternative method for evaluation of air pollution-induced genotoxicity in an urban environment is vegetal biomonitoring. The effects on plants can be used for the qualitative and quantitative evaluation of atmospheric contamination and to delimit risks to biological systems exposed to environmental pollutants [15]. The trees of the genus Bauhinia are a good candidate for small-scale air pollution monitoring because they have been used for street ornamentation and have widespread distribution in cities. Carneiro et al. have demonstrated that the pollen abortion assay in Bauhinia blakeana is effective in determining the area of influence of pollution emissions produced in a traffic corridor [16]. Despite increased numbers of studies using vegetal biomonitoring to assess air pollution effects, only a few studies associated vegetal bioindicators with human health [17] or assessed the relationship between human biomarkers and vegetal bioindicators for genotoxicity [18].

The aim of this study was to evaluate the effects of air pollution in areas with varying population densities via biomonitoring and to compare plant biomonitoring data with genotoxic and mutagenic markers of human exposure to traffic-related air pollution in children. 


\section{Experimental Section}

\subsection{Study Area}

Porto Alegre is the capital of the state of Rio Grande do Sul, located in southern Brazil. It has 1,467,823 inhabitants distributed over $496,827 \mathrm{~km}^{2}$. The climate is humid-subtropical, with consistent and above-average precipitation throughout the year.

Monitoring groups were selected near major streets in three areas with different population profiles. Area A: Protásio Alves Avenue $\left(30^{\circ} 02^{\prime} 22.44^{\prime \prime} \mathrm{S} / 51^{\circ} 10^{\prime} 35.13^{\prime \prime} \mathrm{W}\right)$ - high population density $\left(11,458 \mathrm{pop} / \mathrm{km}^{2}\right)$. Area B: Cavalhada Avenue $\left(30^{\circ} 05^{\prime} 49.69^{\prime \prime} \mathrm{S} / 51^{\circ} 13^{\prime} 44.39^{\prime \prime} \mathrm{W}\right)$-intermediate

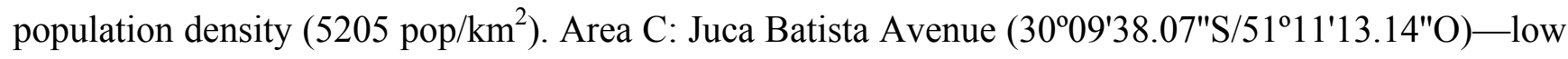
population density $\left(2660 \mathrm{pop} / \mathrm{km}^{2}\right)$. The distance between each site is approximately $7 \mathrm{~km}$. To avoid differences due to spatial distribution of air pollutants, the $\mathrm{NO}_{2}$ and $\mathrm{O}_{3}$ passive sampling data and the pollen abortion assay data were collected at distances of 0, 100 and 200 meters from the main road at each site.

\subsection{Study Population}

Students at public schools in the three study areas of Porto Alegre were invited to participate in the study. Only children living near their respective monitoring areas were selected to ensure that their living and studying regions were similar and to minimize the chance of cross-contamination of pollutants from non-site areas. Children living more than $3 \mathrm{~km}$ from their respective sampling site were excluded from the study. The study was approved by the Ethics Committee of the Federal University of Health Sciences of Porto Alegre (No. 315.260).

\subsection{Nitrogen Dioxide Measurement}

$\mathrm{NO}_{2}$ measurements were collected by passive sampling in winter (June and July 2013) and summer (February and March 2014). Cellulose filters (37 mm, Energética, Rio de Janeiro, Brazil) were impregnated with triethanolamine absorbent solution $(2 \mathrm{~mL})$ and dried at $37{ }^{\circ} \mathrm{C}$ for 24 hours. Filters were then inserted into open diffusion tubes and placed at monitoring sites for 14 days ( $\mathrm{n}=18$ per group). Blanks were obtained from filters exposed in the same conditions but were sealed from atmosphere contact. Nitrite ions are produced when atmospheric $\mathrm{NO}_{2}$ reacts with triethanolamine. These ions were extracted with methanol and reacted with sulfanilamide and 8-anilino-1-naphthalenesulfonic acid (ANSA) [19]. Solutions were then analyzed by spectrophotometry at $550 \mathrm{~nm}$ (Perkin-Elmer Lambda 35, São Paulo, SP, Brazil).

\subsection{Ozone Measurement}

$\mathrm{O}_{3}$ measurement was also conducted by passive sampling during the same period of time as the $\mathrm{NO}_{2}$ measurements. Filters (Energética) were impregnated with indigotine disulphonate (IDS) solution (400 $\mu \mathrm{L}$ ), inserted into open diffusion tubes and placed at monitoring sites for $8 \mathrm{~h}$ ( $\mathrm{n}=18$ per group). Blanks were obtained from filters exposed in the same conditions but were sealed from atmosphere contact. 
After exposure, the filters were removed from the samplers, placed into glass tubes with distilled water $(5 \mathrm{~mL})$ and sonicated in an ultrasonic bath for $5 \mathrm{~min}$. The tubes were then centrifuged for $10 \mathrm{~min}$ at $3800 \mathrm{rpm}$ to clear filter debris. Supernatants were then analyzed by spectrophotometry at $610 \mathrm{~nm}$ (Perkin-Elmer Lambda 35) [20].

\subsection{Pollen Abortion Assay}

The pollen abortion test was chosen as the vegetal biomonitoring assay. The analysis was performed in Bauhinia variegata flower buds located near Areas A, B and C. Flower buds were collected at the end of passive sampling period in winter of 2013.

Flower buds were collected and fixed in $3: 1 \mathrm{v} / \mathrm{v}$ ethanol/acetic acid solution and transferred to $70 \%$ ethanol solution after $24 \mathrm{~h}$. Pollen grains were extracted from anthers and spotted onto slides, which were stained with $0.5 \%$ aceto-carmine for microscopic evaluation. Slides were then photographed with a digital camera (Olympus DP72, Tokyo, Japan) directly attached to the microscope (Olympus BX51, Tokyo, Japan). For each collection area, 300 cells were evaluated per slide, resulting in a total of 9000 cells per area. Pollen abortion criteria consisted of the presence of abnormally large pollen, presence of altered pollen forms, and staining deficiency, as described previously [21].

\subsection{Micronucleus Assay}

Buccal epithelial cells were collected with a wooden spatula from 101 students of public schools in the three study areas of Porto Alegre from June 2013 to March 2014. Cells were collected by rotating the spatula 20 times in a spiral motion against the inner surface of the cheek wall. Samples were stored in $3: 1 \mathrm{v} / \mathrm{v}$ ethanol/acetic acid solution. Afterwards, cells were centrifuged at $1500 \mathrm{rpm}$ for $5 \mathrm{~min}$, and the fixation buffer was changed; this operation was repeated three times. Fixed cells were hydrolyzed in $\mathrm{HCl}$ and stained according to the Feulgen method [22,23]. Micronucleus frequency was determined by counting 1000 cells per sample in duplicate using an optical microscope with $1000 \times$ magnification (Olympus BX51).

Confounding factors for micronucleus frequency include children distribution, socioeconomic status, age, gender, smoking and drinking habits. These factors were controlled for this study by applying the socioeconomic section of International Study of Asthma and Allergies in Childhood (ISAAC) questionnaire [24].

\subsection{Statistical Analysis}

Analysis of the data was performed using the Sigma Plot 12.0 software. The means of the $\mathrm{NO}_{2}$ concentrations, pollen abortion frequency and micronuclei were compared by one-way ANOVA followed by Bonferroni correction. The association between $\mathrm{NO}_{2}$ and pollen abortion was assessed by Pearson Correlation. The influence of confounding factors was assessed by Chi-Square test and one-way ANOVA. The level of significance for these analyses was set at $5 \%$. 


\section{Results}

\subsection{Study Area}

Figure 1 shows the distribution of the studied subjects and monitoring points. The hourly mean traffic flow was collected from public traffic data (Public Company of Transport and Circulation-EPTC) in a single period in each monitoring area. The streets measured were Protásio Alves Avenue (Area A), Cavalhada Avenue (Area B) and Juca Batista Avenue (Area C). Area A averaged 5060 vehicles per hour, 4054 vehicles per hour were measured in Area B and 1607 vehicles per hour passed through Area C.

Figure 1. Subject distribution by monitoring area.

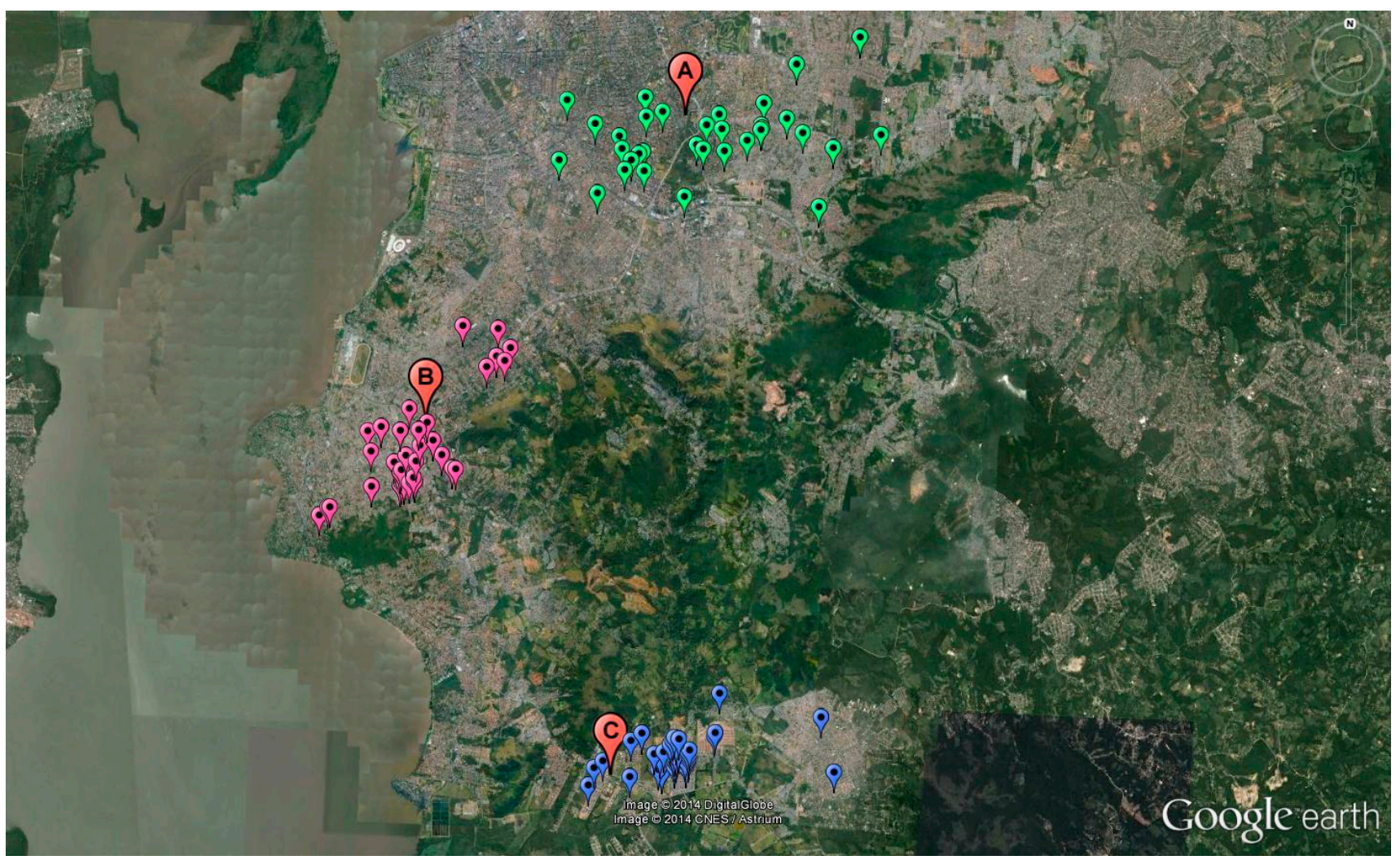

Table 1 presents the environmental conditions in Porto Alegre during the winter and summer sampling periods. The mean summer temperature was $12.2{ }^{\circ} \mathrm{C}$ higher than the mean winter temperature, and the rainfall was $39.4 \mathrm{~mm}$ higher in summer period than in winter [25].

Table 1. Environmental conditions.

\begin{tabular}{llllllll}
\hline Season & $\begin{array}{l}\text { Mean } \\
\text { Temperature } \\
\left({ }^{\mathbf{}} \mathbf{C}\right)\end{array}$ & $\begin{array}{l}\text { Mean Maximum } \\
\text { Temperature } \\
\left({ }^{\circ} \mathbf{C}\right)\end{array}$ & $\begin{array}{l}\text { Mean Minimum } \\
\text { Temperature } \\
\left({ }^{\circ} \mathbf{C}\right)\end{array}$ & $\begin{array}{l}\text { Relative } \\
\text { Humidity } \\
(\mathbf{\%})\end{array}$ & $\begin{array}{l}\text { Total } \\
\text { Rainfall } \\
(\mathbf{m m})\end{array}$ & $\begin{array}{l}\text { Wind } \\
\text { Speed } \\
(\mathbf{m p s})\end{array}$ & $\begin{array}{l}\text { Wind } \\
\text { Direction }\end{array}$ \\
\hline Winter & 14.1 & 19.7 & 10.4 & 82.7 & 216.6 & 1.9 & SE \\
Summer & 24.7 & 30.5 & 20.63 & 76.35 & 274.1 & 2.51 & SE \\
\hline
\end{tabular}




\subsection{Nitrogen Dioxide Measurement}

Nitrogen dioxide concentrations were related with population density and traffic flow. The high population density area showed the highest concentration of $\mathrm{NO}_{2}$, followed by the intermediate and low population density areas. This pattern was maintained in both the summer and winter monitoring periods.

Figure 2 shows the $\mathrm{NO}_{2}$ concentrations by monitoring area in summer (A) and winter (B). The mean concentrations of $\mathrm{NO}_{2}$ in summer were $42.4 \pm 5.0 \mu \mathrm{g} / \mathrm{m}^{3}$ in Group $\mathrm{A}, 22.3 \pm 3.1 \mu \mathrm{g} / \mathrm{m}^{3}$ in Group B and $13.9 \pm 3.0 \mu \mathrm{g} / \mathrm{m}^{3}$ in Group C. All groups were significantly different from each other $(P<0.001)$. In winter, the mean concentrations of $\mathrm{NO}_{2}$ were $42.1 \pm 4.1 \mu \mathrm{g} / \mathrm{m}^{3}$ in Group A, $30.4 \pm 4.2 \mu \mathrm{g} / \mathrm{m}^{3}$ in Group B and $17.1 \pm 7.0 \mu \mathrm{g} / \mathrm{m}^{3}$ in Group C. All groups were significantly different from each other $(P<0.001)$. The data are expressed as the mean \pm standard deviation.

Figure 2. $\mathrm{NO}_{2}$ concentrations in the monitoring areas for summer $(\mathbf{A})$ and winter $(\mathbf{B})$.
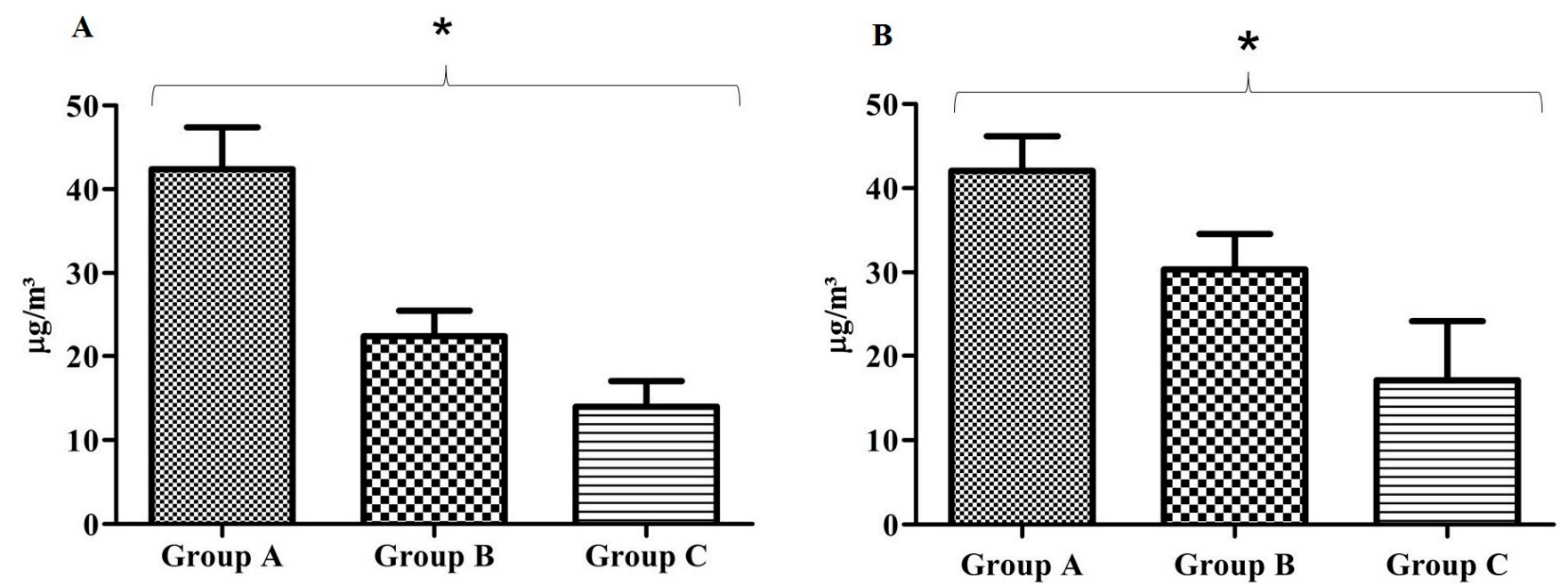

\subsection{Ozone Measurement}

Like $\mathrm{NO}_{2}$, the $\mathrm{O}_{3}$ concentration maintained a consistent distribution pattern during the two seasons. However, unlike the $\mathrm{NO}_{2}$ concentrations across groups, the $\mathrm{O}_{3}$ concentrations were similar between the high and intermediate population groups, and both were higher than the low population density group.

Figure 3 shows the $\mathrm{O}_{3}$ concentration in the monitoring areas in summer (A) and winter (B). In summer, the mean concentration of Group A was $43.2 \pm 8.1 \mu \mathrm{g} / \mathrm{m}^{3}$, whereas Group B had a mean concentration of $44.5 \pm 10.4 \mu \mathrm{g} / \mathrm{m}^{3}$ and Group $C$ had a mean concentration of $34.3 \pm 9.6 \mu \mathrm{g} / \mathrm{m}^{3}$. Groups $\mathrm{A}$ and $\mathrm{B}$ were not different $(P=1.000)$, but both were higher than Group $\mathrm{C}(P=0.030)$. In winter, the mean concentration of $\mathrm{O}_{3}$ in Group A was $35.9 \pm 12.9 \mu \mathrm{g} / \mathrm{m}^{3}$, whereas the mean concentration was $34.9 \pm 9.8 \mu \mathrm{g} / \mathrm{m}^{3}$ in Group B and $23.7 \pm 10.1 \mu \mathrm{g} / \mathrm{m}^{3}$ in Group C. Similar to the data from summer, the $\mathrm{O}_{3}$ concentrations in Groups $\mathrm{A}$ and $\mathrm{B}$ were higher than that in Group $\mathrm{C}(P=0.036)$, but they were not different between themselves $(P=1.000)$. The data are expressed as the mean \pm standard deviation. 
Figure 3. $\mathrm{O}_{3}$ concentrations in the monitoring areas for summer $(\mathbf{A})$ and winter $(\mathbf{B})$.
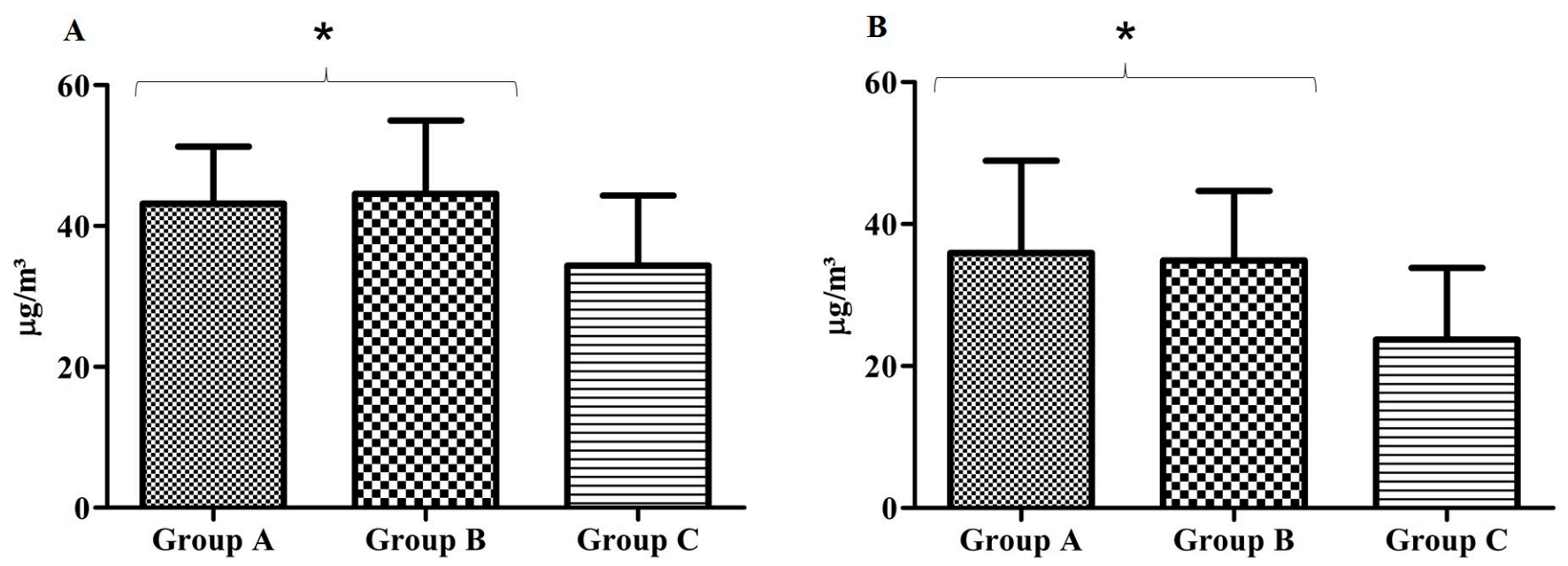

\subsection{Pollen Abortion Assay}

Similar patterns of distribution were found in pollen abortion rates compared with the distributions of $\mathrm{NO}_{2}$ concentration, population density and traffic flow. Group A showed the highest rate of genetic damage, followed by Groups B and C. The pollen abortion rate by monitored area is presented in Figure 4. The mean concentration of Group A was $38.8 \pm 6.5 \mu \mathrm{g} / \mathrm{m}^{3}$, followed by $30.2 \pm 7.6 \mu \mathrm{g} / \mathrm{m}^{3}$ in Group B and $20.9 \pm 5.2 \mu \mathrm{g} / \mathrm{m}^{3}$ in Group C. All groups were significantly different from each other $(P<0.001)$. The data are expressed as the mean damaged cell rate \pm standard deviation.

Figure 4. Pollen abortion rate in monitoring areas.

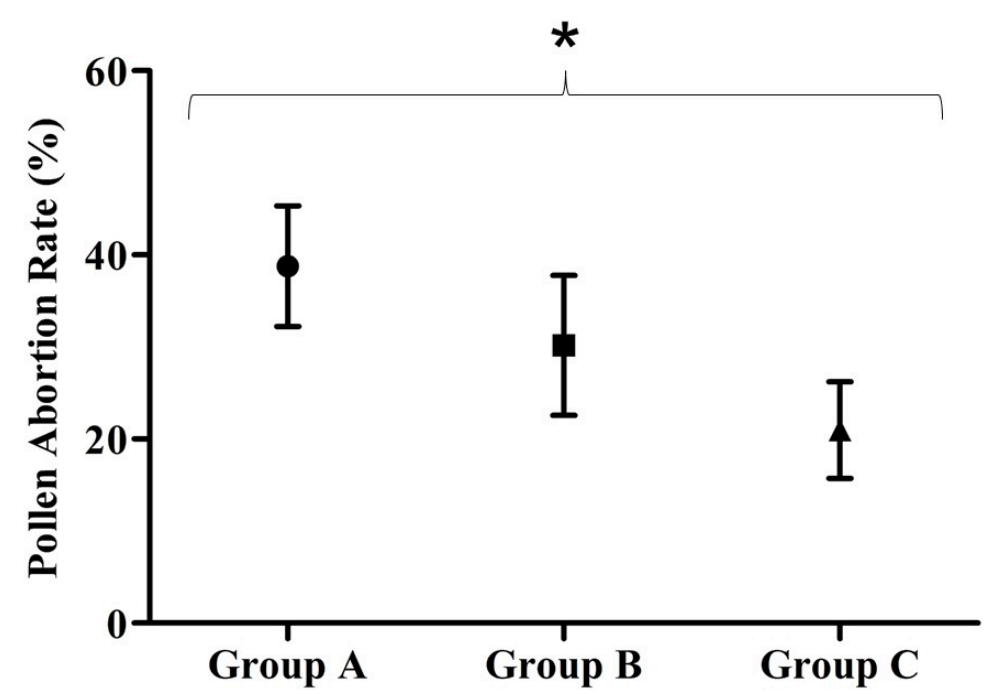

$\mathrm{NO}_{2}$ and pollen abortion were strongly positively correlated $(\mathrm{r}=0.842 ; P=0.004)$, (Figure 5). This correlation demonstrates that the pollen abortion assay, a genotoxicity biomarker, is a good proxy for the degree of air pollution (and corresponding traffic density) in regions with varying population density. 
Figure 5. Positive association between $\mathrm{NO}_{2}$ and pollen abortion.

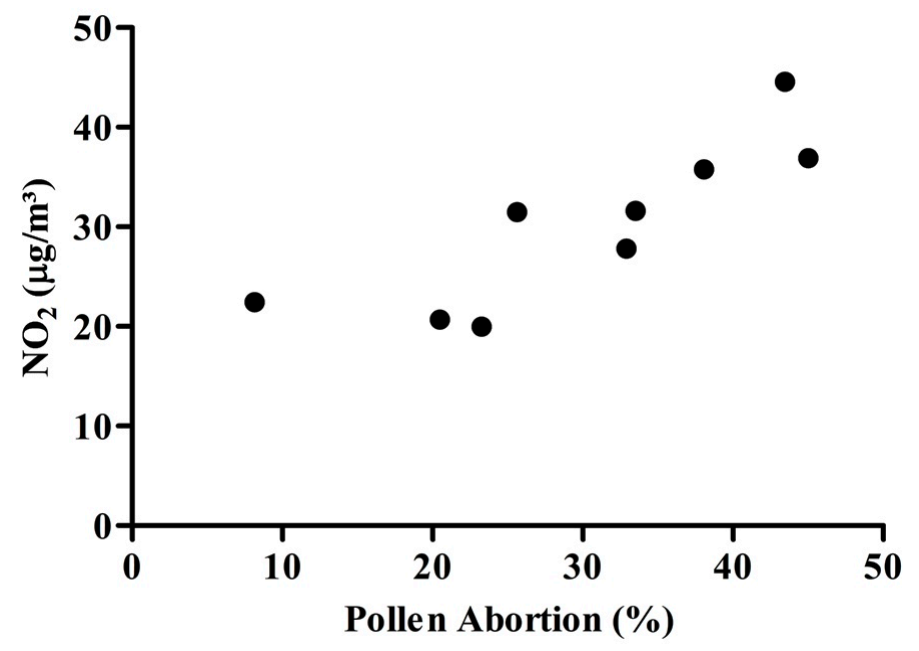

\subsection{Micronucleus Assay}

The micronucleus assay results are presented in Table 2. Group A had a mean of $4.57 \pm 2.05$ micronucleus per 1000 cells, Group B had had a mean of $4.30 \pm 1.89$ micronucleus per 1000 cells and Group $\mathrm{C}$ had a mean of $2.31 \pm 1.10$ micronucleus per 1000 cells. The data are expressed as the mean \pm standard deviation. Groups A and B were similar $(P=1.000)$, but both groups presented a higher rate of genotoxic damage when compared with Group $\mathrm{C}(P<0.001)$. N = number of children. $\mathrm{MCN} / 1000$ cells $=$ Micronucleus per 1000 cells. $\mathrm{SD}=$ standard deviation.

Table 2. Micronucleus frequency.

\begin{tabular}{lcccc}
\hline Groups & N & MCN/1000 Cells & SD & $\boldsymbol{P}$ \\
\hline Group A & 33 & $4.57 *$ & 2.05 & $<0.001$ \\
\hline Group B & 34 & $4.30 *$ & 1.89 & $<0.001$ \\
\hline Group C & 34 & 2.31 & 1.10 & $<0.001$ \\
\hline \multicolumn{5}{c}{ Note: * $P<0.001}$. \\
\end{tabular}

Confounding factors and student profiles are presented in Table 3. There were no significant differences in gender $(P=0.317)$, age $(P=0.084)$, socioeconomic status $(P=0.612)$ or exposure to passive smoking $(P=0.815)$ in the children across the study areas.

Table 3. Children profiles by monitoring area.

\begin{tabular}{|c|c|c|c|c|}
\hline Children Profile & Group A $(n=33)$ & Group B $(n=34)$ & Group C $(n=34)$ & $P$ \\
\hline Age (Years) & $13.7 \pm 1.1$ & $13.7 \pm 1.2$ & $13.1 \pm 0.9$ & 0.084 \\
\hline \multicolumn{5}{|c|}{ Gender } \\
\hline Male & 9 & 14 & 15 & \multirow{2}{*}{0.317} \\
\hline Female & 24 & 20 & 19 & \\
\hline \multicolumn{5}{|c|}{ Socioeconomic Status } \\
\hline$\leq 2$ Minimum Wage & 19 & 22 & 18 & \multirow{2}{*}{0.612} \\
\hline$>2$ Minimum Wage & 14 & 12 & 16 & \\
\hline \multicolumn{5}{|c|}{ Passive Smoking } \\
\hline Yes & 19 & 20 & 22 & \multirow{2}{*}{0.815} \\
\hline No & 14 & 14 & 12 & \\
\hline
\end{tabular}


Thus, there were no differences in student profile factors between study areas that could act as confounders of micronucleus rate, such as gender, age and passive smoking. Children with assumed smoking habits or frequent alcohol consumption were excluded from this study because of known correlations to micronucleus frequency.

\section{Discussion}

To our knowledge, this is the first study at this site to demonstrate a relationship between human and plant biomonitoring assays for genotoxicity to urban pollutants. Our data demonstrate that there are differences in air quality and genotoxic effects in plants and humans in regions with varying population densities near heavy traffic roads. We chose to examine the known pollutant $\mathrm{NO}_{2}$ because its outdoor concentrations are highly related with the degree of urbanization and the frequency of vehicle traffic $[26,27]$. Our study, in which the $\mathrm{NO}_{2}$ concentrations are highly related with vehicular flow and population density, is consistent with these previous studies. However, the $\mathrm{O}_{3}$ and $\mathrm{NO}_{2}$ concentrations displayed a different distribution pattern. In the present study, intermediate and high population areas displayed similar $\mathrm{O}_{3}$ concentrations to each other, and both exhibited elevated concentrations compared with the low population area. The fact that $\mathrm{O}_{3}$ is a secondary pollutant may in part explain the results. The formation of $\mathrm{O}_{3}$ is caused by reactions of the key precursors volatile organic compounds (VOCs) and nitrogen oxides (NOx) in the presence of sunlight, and its distribution in an urban environment is dependent on wind direction and geographic characteristics [28].

The pollen abortion assay was chosen for vegetal biomonitoring. This assay is highly sensitive because the target cells (microspores) are haploid, and it can detect lethal mutations that affect the development of pollen [29]. Several studies have demonstrated the relationship between the pollen abortion assay in wild plants and air pollution from different sources [30,31]. In urban areas, this assay has been shown to be a reliable marker of air pollution that is caused by vehicular emissions near high-traffic streets because pollen cells are sensitive to spatial gradient of air pollutants, including $\mathrm{NO}_{2}$ [16]. In our study, we found a strong positive correlation between the pollen abortion rate and $\mathrm{NO}_{2}$ concentrations, thus confirming the relationship of this vegetal biomarker with the spatial dispersion of air pollution and the degree of urbanization. However, the observed genotoxic effects cannot be explained solely by the $\mathrm{NO}_{2}$ levels. Nitrogen dioxide is a marker of fuel combustion and is correlated with many other compounds in exhaust, including PM, VOCs, black carbon and sulfur dioxide $\left(\mathrm{SO}_{2}\right)$ [32]. These pollutants have known genotoxic effects and were not measured in this study.

Our data show that the frequency of micronuclei in buccal cells of children is higher in more urbanized regions and suggests that human genotoxicity in children is strongly associated with air pollution levels in Porto Alegre. Several studies have shown increased rates of genetic damage in buccal epithelial cells of children exposed to high levels of air pollution in urban areas [33,34] as well as higher susceptibility to air pollution in children [35,36]. Van Leuween et al. found that specific DNA-damage pathways and immune pathways that are responsive to air pollution were active in children but not in adults, demonstrating the increased susceptibility of children to air pollution [37]. Whereas we found a relation between $\mathrm{NO}_{2}$ and vegetal bioindicator, micronucleus frequency was associated with $\mathrm{O}_{3}$ concentrations on the three regions of Porto Alegre. In a study made with children and adults in California, Huen et al. found cytogeneticity in both adults and children who were 
exposed to $\mathrm{O}_{3}$, but associations between traffic proximity and micronucleus frequency were detected only in children, suggesting that children may be more susceptible to genotoxicity caused by traffic pollution [38]. Similarly, Valverde et al. demonstrated that exposure to a polluted urban atmosphere with high ozone concentrations in Mexico promoted DNA damage in young adults [39]. The genotoxic effect of $\mathrm{O}_{3}$ is due to the production of a cascade of free radicals that then react with DNA and affect genomic integrity. At relatively high concentrations, the reaction products can cause extensive DNA damage, and this genotoxic lesion might lead to a mutagenic impact, as observed by the formation of DNA micronuclei [39].

Our data from the pollen abortion test were highly correlated with the $\mathrm{NO}_{2}$ concentration along the urban-rural gradient in Porto Alegre, demonstrating that this assay is an effective marker of the degree of urbanization and could be used in monitoring networks as a marker of urban air pollution effects. Despite no difference was found in buccal micronucleus of high and intermediate population area, human and vegetal exposure were interrelated when comparing high populated and low populated areas in Porto Alegre. Studies that use both plant bioindicators and human biomarkers to evaluate the genotoxic effects of air pollution are still rare. In a study performed in the Amazon region, micronuclei frequency in Tradescantia pallida and human alveolar cells both indicated genotoxic effects of organic PM collected during intense biomass burning period [18].

There were some limitations to this study. We did not measure additional pollutants released in vehicular emissions that are demonstrated genotoxicants, such as PM, PAHs and $\mathrm{SO}_{2}$. In addition, we did not measure individual exposures to $\mathrm{O}_{3}$ and $\mathrm{NO}_{2}$, which precludes studying individual exposures to genotoxic pollutants in the context of an urban-rural gradient. Finally, we were not able to assess vegetal biomonitoring in summer because the flower buds of Bauhinia variegata grow only in winter (July and August).

We associated human and plant biomonitoring in a city using the micronucleus frequency assay in buccal epithelial cells in humans and the pollen abortion assay in Bauhinia variegata. These results are strongly associated with the urbanization gradient near heavily trafficked roads, the population distribution and the concentration of air pollution among areas with high, intermediate or low population density in Porto Alegre.

\section{Conclusions}

In conclusion, high concentrations of air pollutants in Porto Alegre are related with both human and plant genotoxicity. In this study, we have shown that the degree of urbanization is associated with the degree of air pollution, which in turn is related to the level of genotoxic stress in children and plants.

\section{Acknowledgments}

The authors would like to thank Marlise Di Domenico, Paulo Guilherme Markus Lopes and Gabriela Almeida Motta for their technical support and Giuseppe Potrick for his assistance with English manuscript revisions. We also would like to thank CNPq and FAPERGS for financial support. 


\section{Author Contributions}

Alan da Silveira Fleck participated in study design, all analysis and manuscript preparation. Mariana Vieira carried out the pollen abortion assay, passive sampling and data revision. Claudia Rhoden and Sergio Amantea participated in the study design, revision of the results and manuscript preparation. All authors have read and approved the final manuscript.

\section{Conflicts of Interest}

The authors declare no conflict of interest.

\section{References}

1. Traffic-Related Air Pollution: A Critical Review of the Literature on Emissions, Exposure, and Health Effects, Special Report; Health Effects Institute: Boston, MA, USA, 2010.

2. Apeagyei, E.; Bank, M.S.; Spengler, J.D. Distribution of heavy metals in road dust along an urban-rural gradient in Massachusetts. Atmos. Environ. 2011, 45, 2310-2323.

3. Lawson, S.J.; Galbally, I.E.; Powell, J.C.; Keywood, M.D.; Molloy, S.B.; Cheng, M.; Selleck, P.W. The effect of proximity to major roads on indoor air quality in typical Australian dwellings. Atmos. Environ. 2011, 45, 2252-2259.

4. Cakmak, S.; Mahmud, M.; Grgicak-Mannion, A.; Dales, R.E. The influence of neighborhood traffic density on the respiratory health of elementary schoolchildren. Environ. Int. 2012, 39, 128-132.

5. Pope, C.A.; Burnett, R.T.; Thun, M.J.; Calle, E.E.; Krewski, D.; Ito, K.; Thurston, G.D. Lung cancer, cardiopulmonary mortality, and long-term exposure to fine particulate air pollution. JAMA 2002, 287, 1132-1141.

6. Lepeule, J.; Laden, F.; Dockery, D.; Schwartz, J. Chronic exposure to fine particles and mortality: An extended follow-up of the Harvard Six Cities Study from 1974 to 2009. Environ. Health Perspect. 2012, 120, 965-970.

7. Fajersztajn, L.; Veras, M.; Barrozo, L.V.; Saldiva, P. Air pollution: A potentially modifiable risk factor for lung cancer. Nat. Rev. Cancer 2013, 13, 674-678.

8. Santejo Silveira, H.C.; Schmidt-Carrijo, M.; Seidel, E.H.; Scapulatempo-Neto, C.; Longatto-Filho, A.; Carvalho, A.L.; Vieira Reis, R.M.; Nascimento Saldiva, P.H. Emissions generated by sugarcane burning promote genotoxicity in rural workers: A case study in Barretos, Brazil. Environ. Health 2013, 12, doi:10.1186/1476-069X-12-87.

9. Coronas, M.V.; Pereira, T.S.; Rocha, J.A.V.; Lemos, A.T.; Fachel, J.M.G.; Salvadori, D.M.F.; Vargas, V.M.F. Genetic biomonitoring of an urban population exposed to mutagenic airborne pollutants. Environ. Int. 2009, 35, 1023-1029.

10. Hallare, A.V.; Gervasio, M.K.R.; Gervasio, P.L.G.; Acacio-Claro, P.J.B. Monitoring genotoxicity among gasoline station attendants and traffic enforcers in the city of Manila using the micronucleus assay with exfoliated epithelial cells. Environ. Monit. Assess. 2009, 156, 331-341.

11. DeMarini, D.M. Genotoxicity biomarkers associated with exposure to traffic and near-road atmospheres: A review. Mutagenesis 2013, 28, 485-505. 
12. Karahalil, B.; Karakaya, A.E.; Burgaz, S. The micronucleus assay in exfoliated buccal cells: Application to occupational exposure to polycyclic aromatic hydrocarbons. Mutat. Res.-Genet. Toxicol. Environ. Mutagen. 1999, 442, 29-35.

13. Villarini, M.; Moretti, M.; Fatigoni, C.; Agea, E.; Dominici, L.; Mattioli, A.; Volpi, R.; Pasquini, R. Evaluation of primary DNA damage, cytogenetic biomarkers and genetic polymorphisms for CYP1A1 and GSTM1 in road tunnel construction workers. J. Toxicol. Environ. Health Pt. A 2008, 71, 1430-1439.

14. Holland, N.; Bolognesi, C.; Kirsch-Volders, M.; Bonassi, S.; Zeiger, E.; Knasmueller, S.; Fenech, M. The micronucleus assay in human buccal cells as a tool for biomonitoring dna damage: The humn project perspective on current status and knowledge gaps. Mutat. Res.-Rev. Mutat. Res. 2008, 659, 93-108.

15. Savoia, E.J.L.; Domingos, M.; Guimaraes, E.T.; Brumati, F.; Saldiva, P.H.N. Biomonitoring genotoxic risks under the urban weather conditions and polluted atmosphere in Santo Andre, SP, Brazil, through TRAD-MCN bioassay. Ecotoxicol. Environ. Safety 2009, 72, 255-260.

16. Carneiro, M.F.H.; Ribeiro, F.Q.; Fernandes, F.N.; Lobo, D.J.A.; Barbosa, F.; Rhoden, C.R.; Mauad, T.; Saldiva, P.H.N.; Carvalho-Oliveira, R. Pollen abortion rates, nitrogen dioxide by passive diffusive tubes and bioaccumulation in tree barks are effective in the characterization of air pollution. Environ. Exp. Bot. 2011, 72, 272-277.

17. Mariani, R.L.; Jorge, M.P.M.; Pereira, S.S.; Melione, L.P.; Carvalho-Oliveira, R.; Ma, T.H.; Saldiva, P.H.N. Association between micronuclei frequency in pollen mother cells of Tradescantia and mortality due to cancer and cardiovascular diseases: A preliminary study in Sao Jose Dos Campos, Brazil. Environ. Pollut. 2009, 157, 1767-1770.

18. Alves, N.D.O.; Hacon, S.D.S.; de Oliveira Galvao, M.F.; Peixotoc, M.S.; Artaxo, P.; Vasconcellos, P.D.C.; Batistuzzo de Medeiros, S.R. Genetic damage of organic matter in the Brazilian Amazon: A comparative study between intense and moderate biomass burning. Environ. Res. 2014, 130, 51-58.

19. Lodge, J.P.A. Methods of Air Sampling and Analysis; Lewis Publisher Inc.: Chelsea, MI, USA, 1988.

20. Scheeren, B.A.; Adema, E.H. Monitoring ambient ozone with a passive measurement technique method, field results and strategy. Water Air Soil Pollut. 1996, 91, 335-350.

21. Mičieta, K.; Murín, G. Microspore analysis for genotoxicity of a polluted environment. Environ. Exp. Bot. 1996, 36, 21-27.

22. Goncalves da Silva, A.L.; da Rosa, H.T.; Karnopp, T.E.; Charlier, C.F.; Ellwanger, J.H.; Moura, D.J.; Possuelo, L.G.; de Moura Valim, A.R.; Guecheva, T.N.; Pegas Henriques, J.A. Evaluation of dna damage in COPD patients and its correlation with polymorphisms in repair genes. BMC Med. Genet. 2013, 14, doi:10.1186/1471-2350-14-93.

23. Thomas, P.; Holland, N.; Bolognesi, C.; Kirsch-Volders, M.; Bonassi, S.; Zeiger, E.; Knasmueller, S.; Fenech, M. Buccal micronucleus cytome assay. Nat. Protoc. 2009, 4, 825-837.

24. Solé, D.; Vanna, A.; Yamada, E.; Rizzo, M.; Naspitz, C. International Study of Asthma and Allergies in Childhood (ISAAC) written questionnaire: Validation of the asthma component among Brazilian children. J. Invest. Allerg. Clin. Immunol. 1997, 8, 376-382. 
25. Instituto Nacional de Meteorologia. Avaiable online: www.inmet.gov.br (acessed on 25 June 2014).

26. Esplugues, A.; Ballester, F.; Estarlich, M.; Llop, S.; Fuentes, V.; Mantilla, E.; Iniguez, C. Indoor and outdoor concentrations and determinants of $\mathrm{NO}_{2}$ in a cohort of 1-year-old children in Valencia, Spain. Indoor Air 2010, 20, 213-223.

27. Gauderman, W.J.; Avol, E.; Lurmann, F.; Kuenzli, N.; Gilliland, F.; Peters, J.; McConnell, R. Childhood asthma and exposure to traffic and nitrogen dioxide. Epidemiology 2005, 16, 737-743.

28. Sillman, S. The relation between ozone, nox and hydrocarbons in urban and polluted rural environments. Atmos. Environ. 1999, 33, 1821-1845.

29. Misik, M.; Solenska, M.; Micieta, K.; Misikova, K.; Knasmuller, S. In situ monitoring of clastogenicity of ambient air in Bratislava, Slovakia using the Tradescantia micronucleus assay and pollen abortion assays. Mutat. Res.-Genet. Toxicol. Environ. Mutagen. 2006, 605, 1-6.

30. Misik, M.; Micieta, K.; Solenska, M.; Misikova, K.; Pisarcikova, H.; Knasmueller, S. In situ biomonitoring of the genotoxic effects of mixed industrial emissions using the Tradescantia micronucleus and pollen abortion tests with wild life plants: Demonstration of the efficacy of emission controls in an Eastern European city. Environ. Pollut. 2007, 145, 459-466.

31. Uhrikova, A.; Micieta, K. In-situ bioindication of genotoxic effect using the species of native flora in the vicinity of a nickel plant. Biologia 1995, 50, 65-68.

32. Beckerman, B.; Jerrett, M.; Brook, J.R.; Verma, D.K.; Arain, M.A.; Finkelstein, M.M. Correlation of nitrogen dioxide with other traffic pollutants near a major expressway. Atmos. Environ. 2008, 42, 275-290.

33. Chen, C.; Arjomandi, M.; Qin, H.; Balmes, J.; Tager, I.; Holland, N. Cytogenetic damage in buccal epithelia and peripheral lymphocytes of young healthy individuals exposed to ozone. Mutagenesis 2006, 21, 131-137.

34. Lahiri, T.; Roy, S.; Basu, C.; Ganguly, S.; Ray, M.R.; Lahiri, P. Air pollution in Calcutta elicits adverse pulmonary reactions in children. Indian J. Med. Res. 2000, 112, 21-26.

35. Neri, M.; Bonassi, S.; Knudsen, L.E.; Sram, R.J.; Holland, N.; Ugolini, D.; Merlo, D.F. Children's exposure to environmental pollutants and biomarkers of genetic damage: I. Overview and critical issues. Mutat. Res.-Rev. Mutat. Res. 2006, 612, 1-13.

36. Neri, M.; Ugolini, D.; Bonassi, S.; Fucic, A.; Holland, N.; Knudsen, L.E.; Sram, R.J.; Ceppi, M.; Bocchini, V.; Merlo, D.F. Children's exposure to environmental pollutants and biomarkers of genetic damage: II. Results of a comprehensive literature search and meta-analysis. Mutat. Res.-Rev. Mutat. Res. 2006, 612, 14-39.

37. Van Leeuwen, D.M.; Pedersen, M.; Hendriksen, P.J.M.; Boorsma, A.; van Herwijnen, M.H.M.; Gottschalk, R.W.H.; Kirsch-Volders, M.; Knudsen, L.E.; Sram, R.J.; Bajak, E.; et al. Genomic analysis suggests higher susceptibility of children to air pollution. Carcinogenesis 2008, 29, 977-983.

38. Huen, K.; Gunn, L.; Duramad, P.; Jeng, M.; Scalf, R.; Holland, N. Application of a geographic information system to explore associations between air pollution and micronucleus frequencies in African American children and adults. Environ. Mol. Mutagen. 2006, 47, 236-246. 
39. Valverde, M.; Lopez, M.D.C.; Lopez, I.; Sanchez, I.; Fortoul, T.I.; OstroskyWegman, P.; Rojas, E. DNA damage in leukocytes and buccal and nasal epithelial cells of individuals exposed to air pollution in Mexico City. Environ. Mol. Mutagen. 1997, 30, 147-152.

(C) 2014 by the authors; licensee MDPI, Basel, Switzerland. This article is an open access article distributed under the terms and conditions of the Creative Commons Attribution license (http://creativecommons.org/licenses/by/3.0/). 